\title{
Movement patterns of juvenile hawksbill turtles Eretmochelys imbricata at a Caribbean coral atoll: long-term tracking using passive acoustic telemetry
}

\author{
Megan G. Chevis ${ }^{1,2}$, Brendan J. Godley ${ }^{1}$, James P. Lewis ${ }^{3}$, Julie Jackson Lewis ${ }^{2}$, \\ Kylie L. Scales ${ }^{4,5}$, Rachel T. Graham ${ }^{2, *}$ \\ ${ }^{1}$ Centre for Ecology and Conservation, University of Exeter, Penryn Campus, TR10 9EZ, UK \\ ${ }^{2}$ MarAlliance, 32 Coconut Drive/PO Box 283, San Pedro, Ambergris Caye, Belize \\ ${ }^{3}$ Amphibian Survival Alliance, International Conservation House, 7078 Airlie Road, Warrenton, VA 20187, USA \\ ${ }^{4}$ Institute of Marine Sciences, University of California, Santa Cruz, CA 95064, USA \\ ${ }^{5}$ NOAA Southwest Fisheries Center, Environmental Research Division, 99 Pacific Street, Suite \#255A, Monterey, CA 93950, USA
}

\begin{abstract}
Understanding the ecological interactions that underlie marine ecosystem functioning requires sufficient data describing habitat use by mobile species. Hawksbill turtles Eretmochelys imbricata are considered a key species in coral reef-associated communities, owing to their specific foraging preferences, yet new information is still revealing details of the spatial and temporal aspects of habitat use. We used passive acoustic telemetry to monitor the movements of 18 juvenile hawksbills (minimum curved carapace length: $32.0-59.7 \mathrm{~cm}$, mean $\pm \mathrm{SD}=$ $43.9 \pm 6.7 \mathrm{~cm}$ ) at a developmental foraging site in a Mesoamerican barrier reef, Lighthouse Reef Atoll in Belize (tracking duration 10-1414 d, mean $\pm \mathrm{SD}=570 \pm 484 \mathrm{~d}$ ). Although specific home ranges were difficult to quantify, several turtles showed high site fidelity over timescales of months to years, with occasional wide-ranging use of the atoll. Diel variation in the number of detections received strongly suggest nocturnal resting. Long-term tracking data reveal 3 degrees of site fidelity across the atoll, based on the number of detection days near individual stations: high residency ( $n=4$ turtles), sequential residency $(n=5)$, and transient behavior $(n=4)$. These variations in movement raise questions about the differentiation of foraging habitats and degree of individual specialization within this population, as well as the influences of microhabitats and human disturbance.
\end{abstract}

KEY WORDS: Spatial ecology $\cdot$ Home range $\cdot$ Belize $\cdot$ Habitat use $\cdot$ Site fidelity $\cdot$ Marine megafauna $\cdot$ World Heritage Site

\section{INTRODUCTION}

With the host of anthropogenic threats that tropical marine ecosystems are currently facing, our understanding of the processes that regulate biodiversity within these ecosystems becomes increasingly important (Gardner et al. 2003, Halpern et al. 2008). Coral reefs are highly complex ecological communities, hosting numerous interdependent interactions across taxonomic levels, from sponges to mega-vertebrates,

${ }^{*}$ Corresponding author: rachel@maralliance.org including sharks and marine turtles (Paulay 1997, Moberg \& Folke 1999). The decline of coral reefs ultimately affects populations of these mobile species, some of which are already threatened by direct exploitation (Jones et al. 2004, Pratchett et al. 2011, Humber et al. 2014). In some cases, marine protected areas (MPAs) have been successful in safeguarding biodiversity, or at least in preventing the decline of some reef-associated communities that have been degraded by human exploitation (Halpern 2003, Mora

() The authors 2017. Open Access under Creative Commons by Attribution Licence. Use, distribution and reproduction are unrestricted. Authors and original publication must be credited. 
2008, Selig \& Bruno 2010). However, implementation of conservation measures such as MPAs depends on sufficient knowledge of how mobile organisms interact with their habitats and how this behavior may change over time.

The hawksbill turtle Eretmochelys imbricata is a circumtropically distributed species that recruits to coral reef systems after an oceanic post-hatching phase. In the Caribbean, this ontogenetic shift generally occurs at 20 to $35 \mathrm{~cm}$ carapace length (Boulon 1994, Bolten 2003). Juveniles are thought to show high site fidelity within these developmental habitats, maintaining a small home range for extended periods, with individuals selecting different microhabitats depending on size or ontogenetic stage (van Dam \& Diez 1998, Blumenthal et al. 2009a, Wood et al. 2013). Although their feeding ecology remains poorly understood, hawksbills are known to feed on a range of reef-associated invertebrates, with sponges forming a major part of the diet of older juveniles and adults (Carr \& Stancyk 1975, Meylan 1988, León \& Bjorndal 2002). Such specialization suggests that hawksbill foraging ecology plays a critical role in shaping coral reef systems, since the species preferred by these turtles have the potential to outcompete corals without top-down control (Meylan 1988, Hill 1998, León \& Bjorndal 2002). As the largest spongivore in most Caribbean reef systems, hawksbill populations will likely be impacted by shifts in coral reef assemblages and sponge mortality events (Lessios 1988, Meylan 1988, Hughes 1994, Wulff 2006).

In recent years, a wide range of techniques have been used in coral reef environments to begin to describe the ecology of hawksbills. These have ranged from engaging recreational divers (Williams et al. 2015) and photo-identification (Dunbar et al. 2014) to using towed underwater video (Walcott et al. 2014). Tracking technologies have included radio telemetry (Berube et al. 2012), active acoustic telemetry (van Dam \& Diez 1998, Scales et al. 2011), and passive acoustic telemetry (Blumenthal et al. 2009b, Okuyama et al. 2010, Hart et al. 2012). Active acoustic telemetry, in which focal animals are repeatedly located using a small vessel-based directional hydrophone system, has previously revealed that juvenile hawksbill turtles inhabiting Lighthouse Reef Atoll, Belize, have more extensive home ranges than those inhabiting other developmental sites in the Caribbean (Scales et al. 2011), although the nature of data acquisition necessitated short tracking durations $(<25 \mathrm{~d})$. Passive acoustic telemetry is a technique by which focal animals can be tracked using a fixed array of hydrophones, previously used extensively with marine mammals (e.g. Soldevilla et al. 2014, Miller et al. 2015), where animals are detected from their vocalizations, and fish, where animals are equipped with individualized transmitters that are detected by receivers (Heupel \& Hueter 2001, Rhodes \& Tupper 2008, Rowell et al. 2015). Although it can be costly in terms of the initial financial input for receivers and transmitters, and the routine maintenance of equipment, this long-term monitoring enables the continuous collection of data not influenced by survey effort or observer presence (Lowe et al. 2006, Cooke 2008, Zeh et al. 2015).

Here, we aimed to further elucidate use of this major Caribbean developmental site by describing medium- to long-term movement patterns of juvenile hawksbill turtles. More specifically, our tracking study aimed to (1) evaluate evidence of long-term site fidelity and (2) discern the scale and pattern of movement among individuals.

\section{MATERIALS AND METHODS}

\section{Study site}

Lighthouse Reef Atoll (LRA), located approximately $70 \mathrm{~km}$ from mainland Belize, is the most remote of the country's 3 offshore atolls (Fig. 1). Five cayes and 2 MPAs (Blue Hole Natural Monument, BHNM, established in 1996: $4.1 \mathrm{~km}^{2}$ total area; and Half Moon Caye Natural Monument, HMCNM, established in 1982: $39 \mathrm{~km}^{2}$ total area) are within the reef-fringed atoll. BHNM and HMCNM are yearround no-take zones, forming part of the Belize Barrier Reef UNESCO World Heritage Site established in 1996 (Cho 2005). The outer edge of the atoll is spur and groove forereef, which gradually leads to a vertical wall of coral reef, with the shallow lagoon area consisting mostly of sand and patch reef (Perkins \& Carr 1985).

As in other coral reef systems (Pilcher et al. 2015), hawksbills, green turtles Chelonia mydas, and loggerhead turtles Caretta caretta are found in a mixedspecies aggregations at LRA, with hawksbills the most commonly sighted species. Sightings and capture data extending over several years have suggested that the atoll is an important developmental site for juvenile hawksbills and perhaps a stopover foraging site for breeding females (Scales et al. 2011, Graham et al. 2015). 


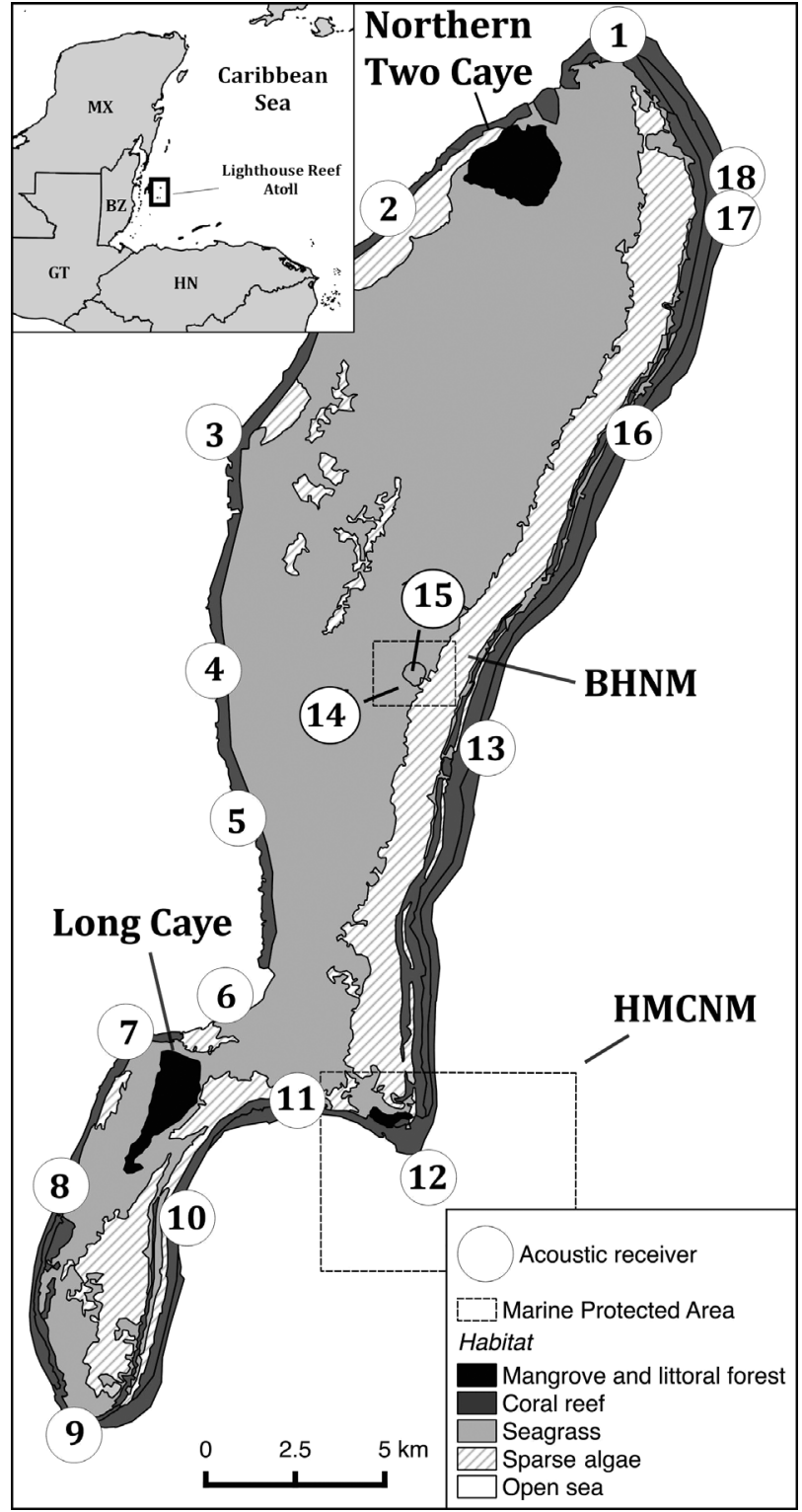

Fig. 1. Study site, Lighthouse Reef Atoll, Belize (17 $19^{\prime} 44^{\prime \prime} \mathrm{N}$, $\left.87^{\circ} 33^{\prime} 3^{\prime \prime} \mathrm{W}\right)$, with the locations of 18 Vemco VR2W Single Channel acoustic receivers (69 kHz) and designated marine protected areas (Blue Hole Natural Monument, BHNM, and Half Moon Caye Natural Monument, HMCNM)

\section{Turtle capture}

Hawksbill turtles were captured on the southwestern forereef of LRA and close to Stns 6, 7, and 8, with the exceptions of turtles $C$ and $Q$, which were captured and released near Stns 5 and 9, respectively (Fig. 1). This area was chosen for its abundance of turtle sightings during transect surveys and because weather and sea conditions limited capture effort on the eastern side of the atoll (Scales et al. 2011). Tur- tles were typically sighted at the surface of the water by snorkelers, who then alerted 1 to 2 free divers designated as turtle catchers. Once a turtle was captured, it was brought aboard an $8 \mathrm{~m}$ panga for measurements and transmitter attachment. Data recorded at time of capture included GPS location (Garmin GPS $72 \mathrm{H}$ ), and water depth (m) (hand-held depth sounder, Hawkeye H22PX). Minimum curved carapace length $\left(\mathrm{CCL}_{\mathrm{min}}\right.$, Bolten 1999) was measured, as was mass (using either a 20 or $50 \mathrm{~kg}$ spring scale and a mesh net). All turtles were tagged with metal Inconel tags on both front flippers.

\section{Acoustic tracking}

Suitable turtles (mass $>5 \mathrm{~kg}$ ) were fitted with Vemco V16-6H $69 \mathrm{kHz}$ coded transmitters (16 mm diameter, $17.3 \mathrm{~g}$ weight in water, $162 \mathrm{~dB}$ power output, 1850 d battery life). Each tag emitted a unique series of 8 pings at random intervals so that individuals could be identified when in range of a receiver within the array, along with date and time information. Transmitters were attached to the posterior marginal scutes of the carapace to minimize drag and maintain submergence even when the turtle was at the surface. The application site on the carapace was first cleaned using a metal paint scraper and coarse sandpaper to remove epibionts and provide a clean surface for attachment. The site was wiped with acetone to remove excess oils and dirt, then allowed to dry. A 2-part marine epoxy (Goop Marine Fix Fast 2 Epoxy Paste, Power Fastners Pure2k) was used to attach the receiver to the carapace. The turtle remained on the boat while the epoxy set, and was then released near the site of capture. Total time between capture and release was less than $2 \mathrm{~h}$.

Eighteen Vemco VR2W Single Channel receivers (69 $\mathrm{kHz}$ ) were placed at locations throughout LRA, with 16 placed along the forereef perimeter and 2 within the lagoon area inside the BHNM (Fig. 1). Receivers were non-overlapping, and average distance between receivers was $5.5 \mathrm{~km}(\mathrm{SD} \pm 2.9$, range $=$ $0.2-12.2 \mathrm{~km})$. Receivers were removed briefly $(<24 \mathrm{~h})$ at least every 6 mo throughout the study period for battery changes and data retrieval.

\section{Data analysis}

To evaluate the scale of movement by turtles, 2 displacement measurements were calculated based on the stations where each transmitter was detected. We 
estimated maximum displacement using the straightline distance between the 2 most distant detectionpositive stations during the entire monitoring period for each turtle. We calculated an additional measurement, viz. circular displacement, to quantify displacement in relation to forereef habitat, since maximum displacements usually spanned the lagoon, i.e. habitat not often used by hawksbills (Scales et al. 2011). Circular displacement was calculated by summing the straight-line distance between all stations between and including the 2 most distant detection-positive stations. Displacement values were only produced for individuals for which detections were recorded at more than 1 station $(\mathrm{n}=16)$. We measured diel displacement for individuals detected at more than 1 station within a $24 \mathrm{~h}$ period $(\mathrm{n}=4)$.

\section{Effects of size}

We used a paired $t$-test to test for differences between the 2 displacement measurements. The effects of size (as $\mathrm{CCL}_{\min }$ and log-transformed mass) on maximum displacement and circular displacement were tested using a generalized linear mixed-effects model, with number of tag days as a random effect to account for varying tag duration among individuals.

\section{Residency}

We specified 2 metrics for each transmitter: detection days, i.e. the number of days on which at least one station detected the transmitter; and tag days, the number of days between tag attachment and the last day a detection was received from that tag. To evaluate the proportion of time in which each turtle was detected near each station, we calculated a residency metric using the percentage of detectionpositive days for each station out of the turtle's total detection days. We analyzed the relationship between displacement and tag duration using Pearson's product-moment correlation test.

\section{Diel variation}

Differences in detection frequencies over the daynight cycle were assessed by calculating the average number of detections per turtle during each hour of the $24 \mathrm{~h}$ period (sunrise $=06: 00 \mathrm{~h}$, sunset $=18: 00 \mathrm{~h}$ based on local sunrise/sunset times). We then calculated a mean across individuals.
All data analyses were performed using $\mathrm{R}$, with graphs created using the 'ggplot2' package and mixed effects models run using the 'nlme' package (Wickham 2009, R Core Team 2014, Pinheiro et al. 2015). All mapping was completed using QGIS (QGIS Development Team 2009). Unless otherwise noted, mean results are presented with standard deviation.

\section{RESULTS}

\section{Monitored individuals}

Twenty-two hawksbills were captured and fitted with acoustic transmitters over 2 field seasons. Transmissions were received by receiving stations at LRA for 18 of these individuals (see Tables S1 \& S2 in the Supplement at www.int-res.com/articles/suppl/n032 p309_supp.pdf). Turtles C to H were caught in 2009 over a $10 \mathrm{~d}$ period and turtles I to $\mathrm{V}$ were caught in 2010 over $24 \mathrm{~d}$. All turtles equipped with transmitters were juveniles (Witzell 1983, <65 cm CCL $\mathrm{CL}_{\min }$ for juveniles), with $\mathrm{CCL}_{\min }$ ranging from 32.0 to $59.7 \mathrm{~cm}$ (mean $=43.9 \pm 6.7 \mathrm{~cm}$; Fig. 2a). Body mass ranged from 5.7 to $34.0 \mathrm{~kg}$ (mean $=12.8 \pm 7.8 \mathrm{~kg}$ ). The number of tag days varied from 10 to $1414 \mathrm{~d}$, with a mean number of days between first and last transmission of $570 \pm 484 \mathrm{~d}$. Twelve turtles had transmission periods lasting over $300 \mathrm{~d}$, with 4 of those individuals transmitting for over $1000 \mathrm{~d}$ after tag attachment (Table S3 in the Supplement).

\section{Displacement}

There was no significant difference between maximum (linear) displacement (range $=6.8-39.8 \mathrm{~km}$, mean $=19.1 \pm 9.7 \mathrm{~km}$ ) and circular displacement values (range $=6.8-45.8 \mathrm{~km}$, mean $=20.3 \pm 11.2 \mathrm{~km}$ ) for individuals that transmitted at more than 1 station ( $\mathrm{n}=16 ; t=2.08, \mathrm{df}=15, \mathrm{p}>0.05$ ).

Turtles tended to stay within range of a single receiver for at least $24 \mathrm{~h}$, although 4 animals (G, M, O, and $\mathrm{S}$ ) were detected at multiple stations within a $24 \mathrm{~h}$ period. These diel displacements (based on distances between receivers) ranged from 2.9 to $16.5 \mathrm{~km}$ $($ mean $=8.1 \pm 4.9 \mathrm{~km})$. We detected no significant effect of turtle size on the extent of spatial displacement (Fig. 2b,c, Table S4).

We found marked differences between the number of detections received during hours of daylight and those received during hours of darkness (Fig. 3). 

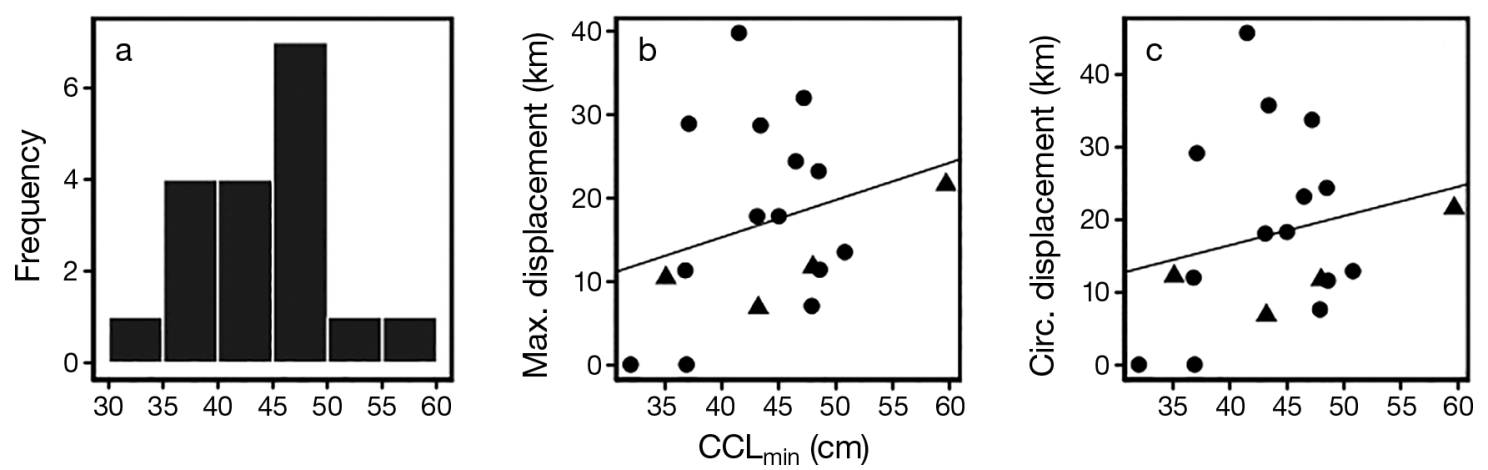

Fig. 2. Size and relative distance traveled by juvenile hawksbill turtles Eretmochelys imbricata successfully monitored with passive acoustic transmitters at Lighthouse Reef Atoll, Belize, in 2009 and 2010 ( $n=18$ ). Triangular data points signify individuals that had fewer than 10 detection days. (a) Size distribution using minimum curved carapace length (CCL $\mathrm{Cin}_{\text {, }} \mathrm{cm}$ ). (b) Comparison of $\mathrm{CCL}_{\min }$ with maximum (straight-line) displacement between stations where each turtle was detected. (c) Comparison of $\mathrm{CCL}_{\min }$ with circular (sum of inter-station distances) displacement. Only turtles detected at more than 1 station were included in (b) and (c)

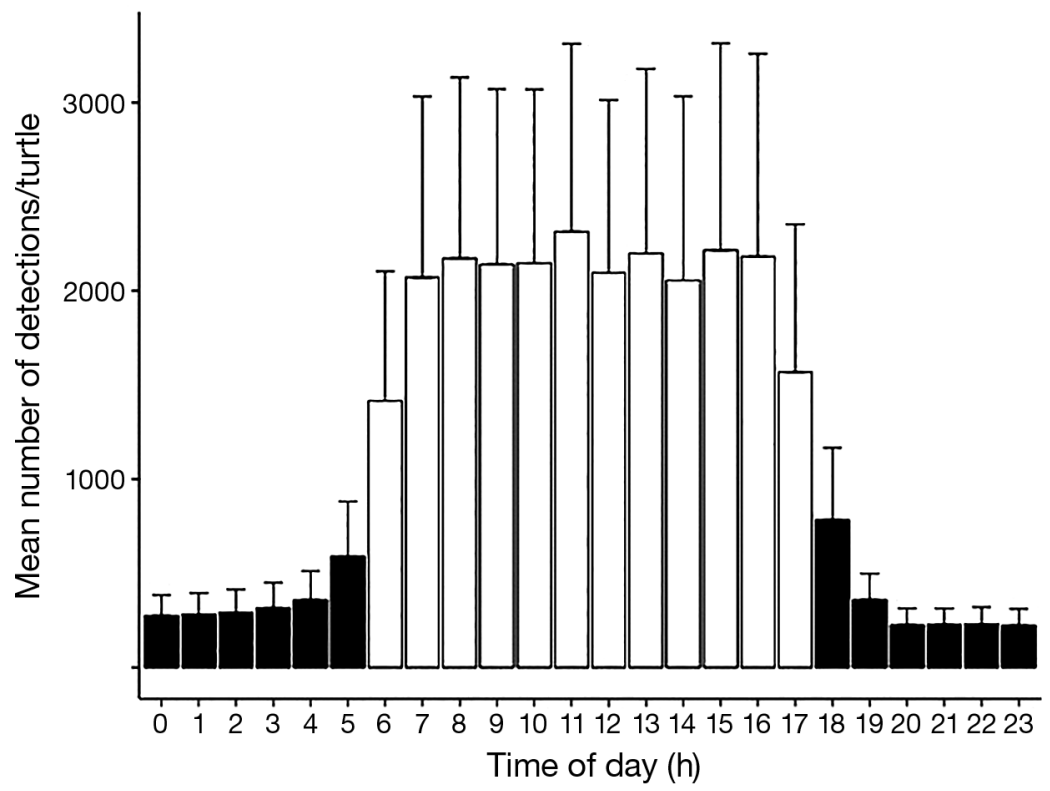

Fig. 3. Diel variation in transmitter detections calculated as the mean (with SE) number of detections per juvenile hawksbill turtle. Black bars denote night time hours; white bars denote daylight hours (and dawn/dusk) based on local times. A higher number of detections during daylight hours was most likely due to changes in activity, with nocturnal resting leading to a significant decrease in the number of detections

\section{Long-term patterns of movement}

Of the 18 stations, Stns 7, 8, and 9 were the most frequently visited. These stations were all located on the southwestern forereef at LRA, close to turtle capture locations (see Table S2 for proportion of detections at each station). For transmitters that received more than 10 detection days, turtles tended to remain close to the capture area, although analysis of indi- vidual movements over time presented different behavioral patterns which could be classified as (1) residents ( $\mathrm{n}=4$ turtles), (2) sequential residents $(n=5)$, and (3) transients $(n=4)$.

Turtles that were considered 'residents' (G, L, M, and T) showed high site fidelity and, although recorded at multiple stations, spent the majority of their time $(60,92,96$, and $100 \%$, respectively) at a single location (Fig. 4: Turtle M; Fig. S1 in the Supplement). Sequential residents showed site fidelity at multiple locations within the atoll, spending several weeks or months near one station before moving to a different location and remaining there for several weeks or months (Fig. 4: Turtle $K_{\text {; }}$ and see Fig. 5). Individuals exhibiting transient behavior were detected at multiple stations within the array over several weeks, remaining around one area for a short period of time (days) before moving on to another area (Fig. 4: Turtle $\mathrm{S}_{\text {; }}$ Fig. S2).

Assessing the movements of individuals between stations over time also highlighted 3 turtles with near-synchronous movement patterns (Fig. 5). All 3 turtles initially remained resident at the same station (Stn 7) for several months, before they were subsequently detected at a different station (Stn 5) within $1 \mathrm{~h}$ of each other. This synchronization of movements apparently continued between several stations (Stns 9 and 7 again) for over $800 \mathrm{~d}$. 

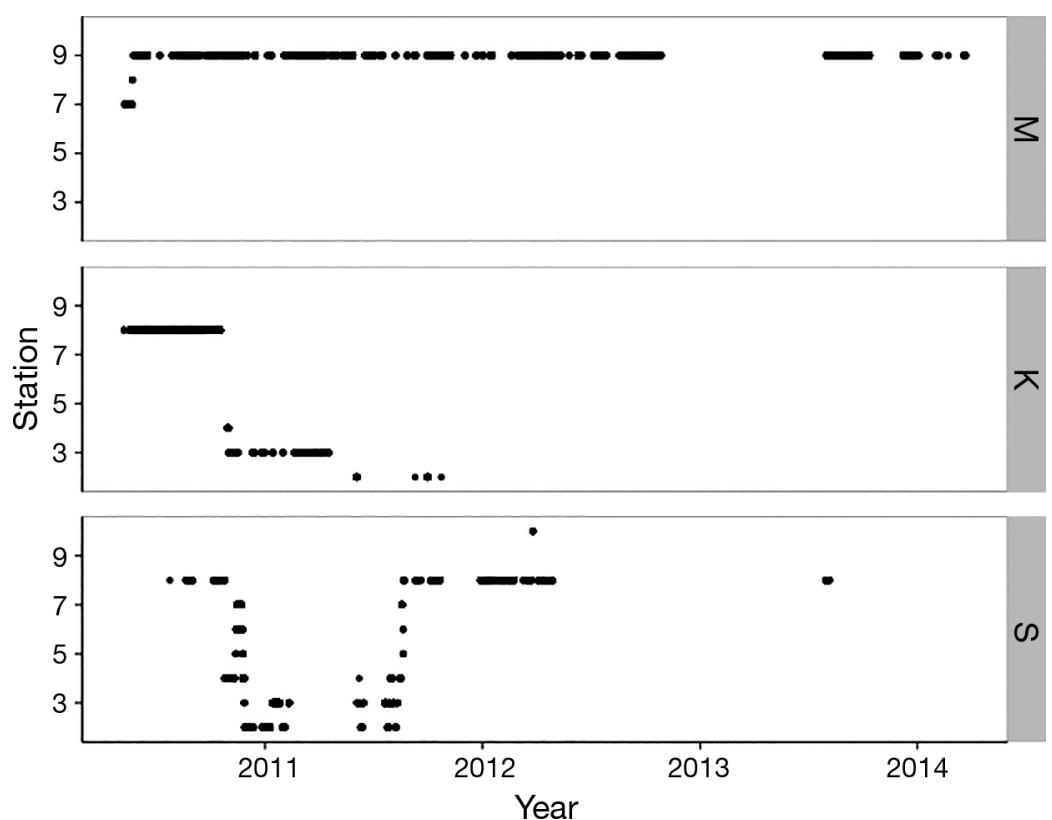

Fig. 4. Locations of detections over time for 3 juvenile hawksbill turtles, each

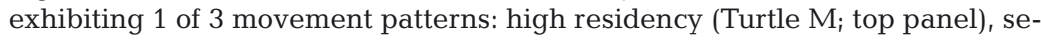
quential residency $\left(K_{i}\right.$ center panel), or transient behavior $\left(S_{i}\right.$ bottom panel). Highly resident individuals were detected for the majority of their transmission period around 1 receiver, while sequential residents were detected for weeks or months around multiple receivers. Transient turtles were detected at multiple stations within the array and were only detected at each receiver for a few days
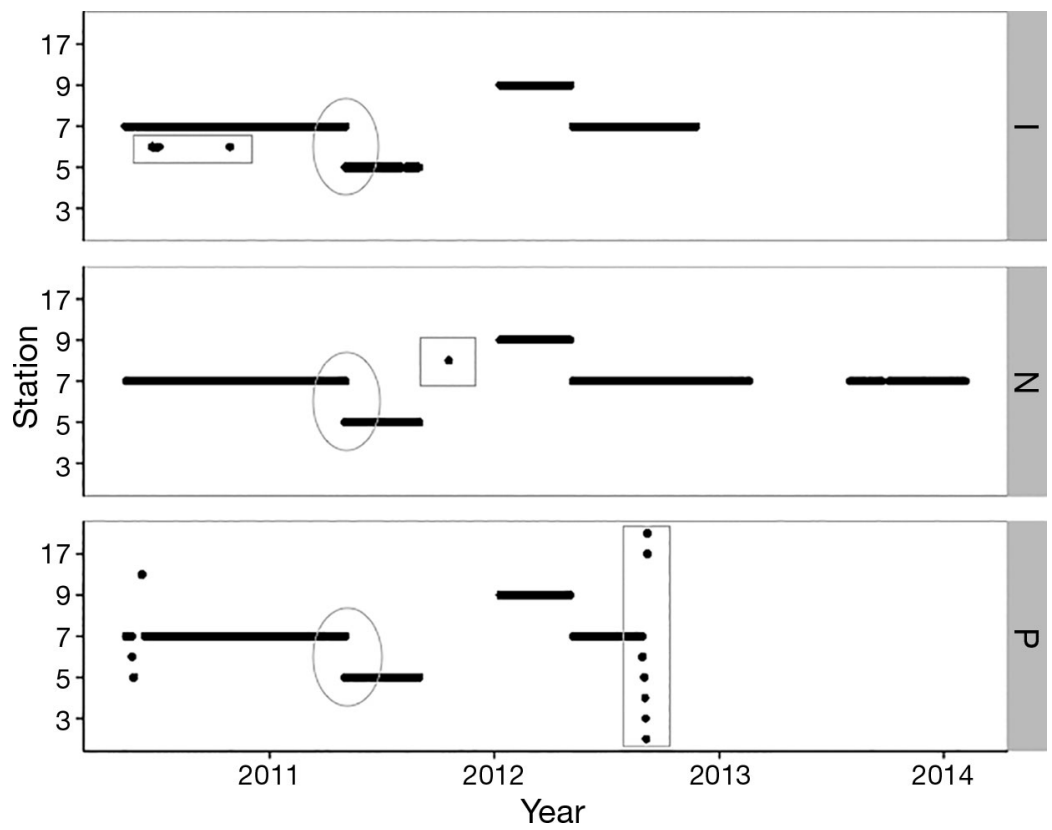

Fig. 5. Activity patterns of 3 monitored juvenile hawksbill turtles (Turtles I, N, and P) that showed very similar movement patterns over a period of almost 2 yr. Ellipses highlight the first simultaneous migration of the turtles from Stn 7 to Stn 5. Outside of these coordinated appearances, each individual transmitter was also detected at other stations in the array, suggesting unique individual movements outside of coordinated movements (rectangles)

\section{DISCUSSION}

\section{Scale of movement}

In general, we observed a considerable level of site fidelity to the study site among juvenile hawksbills within this regionally important developmental foraging habitat, yet individuallevel variation in movement patterns was evident over time scales of months to years. Comparison of our results with those of previous studies that used alternative methods for monitoring can be challenging, largely due to considerable differences in tracking duration. Most studies that have evaluated the home range and displacement of juvenile hawksbills tracked individuals over short periods of time (days to weeks) and subsequently found small home ranges and displacements (Table 1).

Studies that have tracked individuals over longer durations also found greater area utilization, suggesting that short-term monitoring may preclude true evaluation of the extent of movements. The previous assessment of the home range of juvenile hawksbills at LRA by Scales et al. (2011) suggests that some turtles at this site use a much larger area than those tracked in other habitats.

Our findings suggest that, while site fidelity is generally high for many individuals, movements over greater distances are not uncommon. Long-term tracking could therefore be critical in revealing these variations in movements and habitat utilization.

\section{Patterns of movement}

Distinct diel variation in the number of detections received is most likely attributable to nocturnal resting under coral ledges, where receivers are unable to detect acoustic signals from transmitters (van Dam \& Diez 1997, Blumenthal et al. 2009b, Okuyama et al. 2010, Witt et al. 2010, Hart et al. 
Table 1. Summary of results from studies analyzing home range and/or displacement of juvenile and adult hawksbill turtles Eretmochelys imbricata at foraging sites. SCL: straight carapace length, CCL: curved carapace length, CMR: capture-mark-recapture, MCP: minimum convex polygon, KDE: kernel density estimate, UD: utilized distribution. Gaps indicate that variable was not assessed

\begin{tabular}{|c|c|c|c|c|c|c|}
\hline Turtle size $(\mathrm{cm})$ & Home range $\left(\mathrm{km}^{2}\right)$ & $\begin{array}{l}\text { Displacement } \\
(\mathrm{km})\end{array}$ & $\begin{array}{l}\text { Time scale } \\
\text { (d) }\end{array}$ & Method & $\begin{array}{l}\text { Sample } \\
\text { size }\end{array}$ & Reference \\
\hline 28.7-35.6 (SCL) & $0.15-0.55$ (MCP) & & $15-60$ & Radio telemetry & 6 & Berube et al. (2012) \\
\hline 33.0-48.6 (CCL) & $0.05-1.1(\mathrm{MCP})$ & $0.45-8.4$ & $6-25$ & Active acoustic telemetry & 19 & Scales et al. (2011) \\
\hline 37.6-50.4 (SCL) & $0.07-0.14$ (MCP) & $0.69-1.42$ & $11-16$ & Active acoustic telemetry & 3 & van Dam \& Diez (1998) \\
\hline 27.1-51.6 (SCL) & & $0.1-0.3$ & $10-12$ & CMR & 5 & van Dam \& Diez (1997) \\
\hline 20.0-56.7 (SCL) & & $0.0-5.22$ & $9-1118$ & CMR & 87 & van Dam \& Diez (1998) \\
\hline 26.4-58.4 (SCL) & & $\begin{array}{c}0.06-2.08 \\
(10 \mathrm{~km}, \mathrm{n}=1)\end{array}$ & $11-316$ & CMR & 21 & Blumenthal et al. (2009b) \\
\hline 51.9-69.8 (SCL) & $9.2-21.5$ (50\% KDE) & & $320-884$ & $\begin{array}{l}\text { Satellite telemetry, } \\
\text { passive acoustic }\end{array}$ & 3 & Hart et al. (2012) \\
\hline 49.1-70.6 (SCL) & $\begin{array}{c}1.1-19.0(\mathrm{MCP}) \\
0.01-1.2(95 \% \mathrm{KDE})\end{array}$ & & $102-429$ & Satellite telemetry & 6 & Wood et al. (2017) \\
\hline 88-90 (CCL) & 1.96-49.5 (MCP) & & $225-540$ & Satellite telemetry & 4 & Horrocks et al. (2001) \\
\hline 74-93 (CCL) & $\begin{array}{c}0.86-27.63(90 \% \text { UD) } \\
0.06-5.86 \text { (50\% UD) }\end{array}$ & & $2.1-409.9$ & Satellite telemetry & 11 & Gaos et al. (2012) \\
\hline 86.0-106.5 (CCL) & $\begin{array}{c}225.7-2192.3 \text { (MCP) } \\
91.8-286.9 \text { (50\% UD) }\end{array}$ & & $116-722$ & Satellite telemetry & 15 & Marcovaldi et al. (2012) \\
\hline
\end{tabular}

2012, R. T. Graham unpubl. data, M. G. Chevis pers. obs.). Additionally, resting locations may have been in areas outside the range of the receivers and away from foraging sites, a characteristic previously found in juvenile green turtles (Ogden et al. 1983, Blumenthal et al. 2010).

Turtles generally showed site fidelity to LRA and specifically to the area close to their capture sites, but several individuals also spent time in other areas of the atoll. Of particular interest were individual-level variations in movement patterns, which leads to further questions regarding how the regional population uses this habitat and the ecological mechanisms underlying different behaviors. This evidence adds to that found in other sites within the Caribbean (Moncada et al. 2012, Revuelta et al. 2015), suggesting that locally increased marine protection in the area might positively impact this species and also lead to hawksbills being used as an alternate umbrella species for coral reefs (Weng et al. 2015).

Turtles showing sequential residency and exploratory behaviors exhibited periods of high site fidelity, but also made small-scale migrations within their overall foraging site. Small-scale movements between sites could be linked to differences in foraging preferences, strategies prompted by competition in resources from conspecifics, differences in the availability or quality of resources, ontogenetic shifts in habitat, threats from predators, human disturbance, or even behavioral differences linked to individual personality (Bolnick et al. 2003, Bowler \& Benton 2005, Meylan et al. 2011, Wilson \& Krause 2012).

\section{Effectiveness of passive acoustic telemetry}

Using a long-term acoustic array conferred several advantages in generating an understanding of hawksbill spatial ecology. Although our measurements of spatial displacement cannot be considered as equivalent to the true distances traveled by turtles, since a detection at a station meant the animal was within a range that could span several hundred meters (Kessel et al. 2014), these metrics have enabled comparisons of movements among individuals within this study and are a useful proxy for range of movement.

Many of the turtles in this study were monitored over several years, supporting previous hypotheses that hawksbills exhibit site fidelity to foraging areas for substantial periods of time. However, analysis of these data has revealed several caveats to this methodology and specifically the setup of this array. Although the detections from 13 individuals provided enough data to discern patterns of movement and calculate residency, there were limited or no detections from 9 individuals. Lack of detections could be due to tag shedding, receiver failure, turtle dispersal or mortality, the large distances between receivers combined with limited range, or a combination of several or all of these factors.

Four individuals exhibited behavior characterized as 'highly residential,' as they were detected for the majority of their transmission period around 1 receiver. It should be noted that, since the turtles monitored in this study were not visually located periodically, it is uncertain whether these transmitters were 
still attached to turtles or had fallen off within the vicinity of a receiver and continued to transmit until tag failure or water currents moved them outside of the range of the receiver.

The movements of each turtle included 'gap periods' during which no receiver within the array detected that transmitter. These gaps varied from a few days to several weeks or even longer, such as in the case of Turtle $\mathrm{H}$, whose first and last detections spanned $>1$ yr. Although the batteries for each receiver were changed at least annually, and usually semi-annually, battery failure could have accounted for these gaps in detections. Acoustic interference or limited detection range resulting from competing noise or changes in environmental conditions or transmitter error could also have affected detections (Hazel 2009, Kessel et al. 2015). As found in other species, typically at higher latitudes (Fukuoka et al. 2015), individuals could have left the atoll for periods of time before returning again. Since none of the hawksbills monitored in this study were large enough to be considered breeding adults, it is unlikely that they moved to breeding or nesting grounds, but perhaps were using habitat in parts of LRA not within range of a receiver.

Range tests conducted for receiver stations at LRA indicate a maximum range radius of $125 \mathrm{~m}$ at the sites of highest habitat rugosity, with depth of the receiver significantly affecting detection range (J. P. Lewis unpublished data). Similar studies assessing acoustic receivers in coral reef habitats found detection ranges varied between 90 and $200 \mathrm{~m}$, with environmental conditions considerably affecting detectability of a transmitter (Welsh et al. 2012, Kessel et al. 2014). The extensive spacing between receivers in the current study causes difficulty in fully understanding the movements of turtles tracked here. Acoustic receivers installed at LRA were originally meant to monitor the movements of large groupers and sharks that covered forereef coral reef promontory and non-promontory sites. Receivers located in the atoll's northeast corner (nos. 17 and 18) were specifically established in close proximity to one another to provide more comprehensive coverage of a spawning aggregation of Nassau grouper Epinephelus striatus. For a more thorough understanding of the fine-scale movement of turtles at LRA, stations would need to be much closer or form a grid-like pattern that would cover multiple habitat types across the atoll. However, the installation and maintenance of an array of that size would require significantly more time and resources than are currently available.

\section{Synchronous movements}

The 3 individuals with synchronized movements lasting nearly 2 yr (Fig. 5) present a perplexing phenomenon and raise questions about the dynamics of hawksbill social behavior. Multiple detections were received from each transmitter during each detection day, eliminating false detections, and the diel variations of all 3 turtles followed the general diurnal activity pattern seen in the other monitored turtles (although all 3 were unique). Ideally, intermittent sightings of tracked individuals would confirm that detections such as these are valid, provide insight into gap periods in turtles' movements, and determine loss of transmitters. This was not possible in this case as the reason for using passive acoustic monitoring techniques was due to the remoteness and logistical challenges of operating at the site. There are still many aspects of turtle behavior that we have yet to fully understand. Non-breeding interactions among adult (Schofield et al. 2007) and juvenile (in captivity: Higgins 2003) marine turtles have previously been documented, but these events were generally short and aggressive in nature. However, Schofield et al. (2009) found that adult loggerhead turtles at an internesting site in the Mediterranean congregate in selected areas due to preference for warmer microhabitats. Although examples of social behavior and synchronous movements among juvenile hawksbills have so far not been documented, our data suggest that there is potential interaction among individuals. Additional data on factors that could have initiated this behavior, such as increased fishing pressure in the area, predator presence, and changes in food availability or environmental conditions would also provide insight into these movements.

\section{Future directions}

Movements of turtles can be linked with predation (Heithaus et al. 2008, Hammerschlag et al. 2015), environmental change (Pike 2008, Schofield et al. 2009), or anthropogenic pressure, to distinguish what factors affect turtle foraging, migration, and development (Taquet et al. 2006, Heithaus 2013). While our study has provided valuable data regarding the movements of juvenile hawksbill turtles around an offshore developmental habitat, other methods of long-term monitoring, such as satellite telemetry and stable isotope analysis, would permit insights even if tracked individuals were to leave the atoll (Shimada et al. 2014). Technological advances aside, with suffi- 
cient commitment of time and resources, there is also much still to be gained from traditional capturemark-recapture methods (Patrício et al. 2014). What will ultimately enable a more complete understanding of the niche that hawksbills fill within reef ecosystems is an integrative approach, in which multiple methods, populations, and locations are used to fill the gaps in ecology (Hart \& Hyrenbach 2009, Godley et al. 2010, Scales et al. 2011). This study demonstrates that passive acoustic telemetry using fixed receiver arrays could prove to be an important component of this integrated approach, generating detailed insights into movements over timescales of months to years, and providing valuable data on the variation in spatial utilization among individuals.

Acknowledgements. Support was provided by MarAlliance, The Summit Foundation, British Chelonia Group, Wildlife Conservation Society, and the Mitchell-Petersen Family Foundation. We recognize the initial team that captured turtles and collected acoustic data during the 2009/2010 field seasons: Daniel Castellanos Sr., Dan Castellanos, Jason Castro, Darren Castellanos, Demian Garbutt, Alex Garbutt, Mason Cuevas, Kevin Castellanos, Orrington Burgess, and Alistair Daly; thanks to Ivy Baremore for assistance with data analysis. We also thank the anonymous reviewers for their suggestions that improved the manuscript.

\section{LITERATURE CITED}

Berube MD, Dunbar SG, Rützler K, Hayes WK (2012) Home range and foraging ecology of juvenile hawksbill sea turtles (Eretmochelys imbricata) on inshore reefs of Honduras. Chelonian Conserv Biol 11:33-43

Blumenthal JM, Austin TJ, Bell CDL, Bothwell JB, Broderick AC, Solomon JL, Godley BJ (2009a) Ecology of hawksbill turtles, Eretmochelys imbricata, on a western Caribbean foraging ground. Chelonian Conserv Biol 8:1-10

Blumenthal JM, Austin TJ, Bothwell JB, Broderick C and others (2009b) Diving behavior and movements of juvenile hawksbill turtles Eretmochelys imbricata on a Caribbean coral reef. Coral Reefs 28:55-65

Blumenthal JM, Austin TJ, Bothwell JB, Broderick AC and others (2010) Life in (and out of) the lagoon: fine-scale movements of green turtles tracked using time-depth recorders. Aquat Biol 9:113-121

Bolnick DI, Svanbäck R, Fordyce JA, Yang LH, Davis JM, Hulsey CD, Forister ML (2003) The ecology of individuals: incidence and implications of individual specialization. Am Nat 161:1-28

Bolten AB (1999) Techniques for measuring sea turtles. In: Eckert KL, Bjorndal KA, Abreu-Grobois FA, Donnelly M (eds) Research and management techniques for the conservation of sea turtles, $4^{\text {th }}$ edn. IUCN/SSC Marine Turtle Specialist Group, Washington, DC, p 110-114

Bolten AB (2003) Variations in sea turtle life history patterns: neritic vs. oceanic developmental stages. In: Lutz PL, Musick J, Wyneken J (eds) The biology of sea turtles, Vol. II. CRC Press, Boca Raton, FL, p 243-257

Boulon RH (1994) Growth rates of wild juvenile hawksbill turtles, Eretmochelys imbricata, in St. Thomas, United States Virgin Islands. Copeia 1994:811-814

*Bowler DE, Benton TG (2005) Causes and consequences of animal dispersal strategies: relating individual behaviour to spatial dynamics. Biol Rev Camb Philos Soc 80:205-225

Carr A, Stancyk S (1975) Observations on the ecology and survival outlook of the hawksbill turtle. Biol Conserv 8: 161-172

* Cho L (2005) Marine protected areas: a tool for integrated coastal management in Belize. Ocean Coast Manag 48: 932-947

* Cooke SJ (2008) Biotelemetry and biologging in endangered species research and animal conservation: relevance to regional, national, and IUCN Red List threat assessments. Endang Species Res 4:165-185

* Dunbar SG, Ito HE, Bahjri K, Dehom S, Salinas L (2014) Recognition of juvenile hawksbills Eretmochelys imbricata through face scale digitization and automated searching. Endang Species Res 26:137-146

Fukuoka T, Narazaki T, Sato K (2015) Summer-restricted migration of green turtles Chelonia mydas to a temperate habitat of the northwest Pacific Ocean. Endang Species Res 28:1-10

*Gaos AR, Lewison RL, Wallace BP, Yañez IL and others (2012) Spatial ecology of critically endangered hawksbill turtles Eretmochelys imbricata: implications for management and conservation. Mar Ecol Prog Ser 450:181-194

*Gardner TA, Côté IM, Gill JA, Grant A, Watkinson AR (2003) Long-term region-wide declines in Caribbean corals. Science 301:958-960

Godley BJ, Barbosa C, Bruford M, Broderick AC and others (2010) Unravelling migratory connectivity in marine turtles using multiple methods. J Appl Ecol 47:769-778

Graham RT, Baremore I, Chevis MG, Blow G, Salazar H (2015) Annual technical report on research conducted in Belize. MarAlliance, San Pedro

*Halpern BS (2003) The impact of marine reserves: Do reserves work and does reserve size matter? Ecol Appl 13:117-137

*Halpern BS, Walbridge S, Selkoe K, Kappel C, Micheli F, Watson R (2008) A global map of human impact on marine ecosystems. Science 319:948-952

*Hammerschlag N, Broderick AC, Coker JW, Coyne MS and others (2015) Evaluating the landscape of fear between apex predatory sharks and mobile sea turtles across a large dynamic seascape. Ecology 96:2117-2126

* Hart M, Hyrenbach KD (2009) Satellite telemetry of marine megavertebrates: the coming of age of an experimental science. Endang Species Res 10:9-20

* Hart KM, Sartain AR, Fujisaki I, Pratt HL Jr, Morley D, Feeley MW (2012) Home range, habitat use, and migrations of hawksbill turtles tracked from Dry Tortugas National Park, Florida, USA. Mar Ecol Prog Ser 457:193-207

Hazel J (2009) Evaluation of fast-acquisition GPS in stationary tests and fine-scale tracking of green turtles. J Exp Mar Biol Ecol 374:58-68

Heithaus MR (2013) Predators, prey, and the ecological roles of sea turtles. In: Wyneken J, Lohmann KJ, Musick JA (eds) The biology of sea turtles, Vol 3. CRC Press, Boca Raton, FL, p 249-278

Heithaus MR, Frid A, Wirsing AJ, Worm B (2008) Predicting ecological consequences of marine top predator declines. Trends Ecol Evol 23:202-210

Heupel MR, Hueter RE (2001) Use of an automated acoustic telemetry system to passively track juvenile blacktip 
shark movements. In: Sibert JR, Nielson JL (eds) Electronic tagging and tracking in marine fisheries Proceedings. Kluwer Academic Publishers, Dordrecht, p 217-236

Higgins BM (2003) Sea turtle husbandry. In: Lutz PL, Musick JA, Wyneken J (eds) The biology of sea turtles, Vol II. CRC Press, Boca Raton, FL, p 411-440

Hill MS (1998) Spongivory on Caribbean reefs releases corals from competition with sponges. Oecologia 117:143-150

Horrocks JA, Vermeer LA, Krueger B, Coyne M, Schroeder BA, Balazs GH (2001) Migration routes and destination characteristics of post-nesting hawksbill turtles satellitetracked from Barbados, West Indies. Chelonian Conserv Biol 4:107-114

Hughes TP (1994) Catastrophes, phase shifts, and largescale degradation of a Caribbean coral reef. Science 265: 1547-1551

Humber F, Godley BJ, Broderick AC (2014) So excellent a fishe: a global overview of legal marine turtle fisheries. Divers Distrib 20:579-590

Jones GP, McCormick MI, Srinivasan M, Eagle JV (2004) Coral decline threatens fish biodiversity in marine reserves. Proc Natl Acad Sci USA 101:8251-8253

Kessel ST, Cooke SJ, Heupel MR, Hussey NE, Simpfendorfer CA, Vagle S, Fisk AT (2014) A review of detection range testing in aquatic passive acoustic telemetry studies. Rev Fish Biol Fish 24:199-218

Kessel ST, Hussey NE, Webber DM, Gruber SH, Young JM, Smale MJ, Fisk AT (2015) Close proximity detection interference with acoustic telemetry: the importance of considering tag power output in low ambient noise environments. Anim Biotelem 3:1-14

KLeón YM, Bjorndal KA (2002) Selective feeding in the hawksbill turtle, an important predator in coral reef ecosystems. Mar Ecol Prog Ser 245:249-258

Lessios H (1988) Mass mortality of Diadema antillarum in the Caribbean: What have we learned? Annu Rev Ecol Syst 19:371-393

Lowe CG, Wetherbee BM, Meyer CG (2006) Using acoustic telemetry monitoring techniques to quantify movement patterns and site fidelity of sharks and giant trevally around French Frigate Shoals and Midway Atoll. Atoll Res Bull 543:281-303

Marcovaldi MA, Lopez GG, Soares LS, López-Mendilaharsu M (2012) Satellite tracking of hawksbill turtles Eretmochelys imbricata nesting in northern Bahia, Brazil: turtle movements and foraging destinations. Endang Species Res 17:123-132

Meylan A (1988) Spongivory in hawksbill turtles: a diet of glass. Science 239:393-395

Meylan PA, Meylan AB, Gray JA (2011) The ecology and migrations of sea turtles, 8. Tests of the developmental habitat hypothesis. Bull Am Mus Nat Hist 357:1-70

Miller BS, Barlow J, Calderan S, Collins K and others (2015) Validating the reliability of passive acoustic localisation: a novel method for encountering rare and remote Antarctic blue whales. Endang Species Res 26:257-269

Moberg F, Folke C (1999) Ecological goods and services of coral reef ecosystems. Ecol Econ 29:215-233

Moncada FG, Hawkes LA, Fish MR, Godley BJ and others (2012) Patterns of dispersal of hawksbill turtles from the Cuban shelf inform scale of conservation and management. Biol Conserv 148:191-199

Mora C (2008) A clear human footprint in the coral reefs of the Caribbean. Proc R Soc Lond B Biol Sci 275:767-773 * Ogden JC, Robinson L, Whitlock K, Daganhardt H, Cebula
R (1983) Diel foraging patterns in juvenile green turtles (Chelonia mydas L.) in St. Croix United States Virgin Islands. J Exp Mar Biol Ecol 66:199-205

* Okuyama J, Shimizu T, Abe O, Yoseda K, Arai N (2010) Wild versus head-started hawksbill turtles Eretmochelys imbricata: post-release behavior and feeding adaptions. Endang Species Res 10:181-190

* Patrício R, Diez CE, van Dam RP (2014) Spatial and temporal variability of immature green turtle abundance and somatic growth in Puerto Rico. Endang Species Res 23: 51-62

Paulay G (1997) Diversity and distribution of reef organisms. In: Birkeland C (ed) Life and death of coral reefs. Chapman \& Hall, New York, NY, p 298-353

*Perkins JS, Carr A (1985) The Belize barrier reef: status and prospects for conservation management. Biol Conserv 31:291-301

Pike DA (2008) Environmental correlates of nesting in loggerhead turtles, Caretta caretta. Anim Behav 76:603-610

* Pilcher NJ, Al-Maslamani I, Williams J, Gasang R, Chikhi A (2015) Population structure of marine turtles in coastal waters of Qatar. Endang Species Res 28:163-174

Pinheiro J, Bates D, DebRoy S, Sarkar D, R Core Team (2015) nlme: linear and nonlinear mixed effects models. $\mathrm{R}$ package version 3.1-131. http://CRAN.R-project.org/package $=$ nlme

* Pratchett MS, Hoey AS, Wilson SK, Messmer V, Graham NAJ (2011) Changes in biodiversity and functioning of reef fish assemblages following coral bleaching and coral loss. Diversity 3:424-452

QGIS Development Team (2009) QGIS geographic information system. Open Source Geospatial Foundation. http:// qgis.osgeo.org

R Core Team (2014) R: a language and environment for statistical computing. R Foundation for Statistical Computing, Vienna. www.r-project.org

* Revuelta O, Hawkes L, León YM, Godley BJ, Raga JA, Tomás J (2015) Evaluating the importance of Marine Protected Areas for the conservation of hawksbill turtles Eretmochelys imbricata nesting in the Dominican Republic. Endang Species Res 27:169-180

Rhodes KL, Tupper MH (2008) The vulnerability of reproductively active squaretail coralgrouper (Plectropomus areolatus) to fishing. Fish Bull 106:194-204

* Rowell TJ, Nemeth RS, Schärer MT, Appeldoorn RS (2015) Fish sound production and acoustic telemetry reveal behaviors and spatial patterns associated with spawning aggregations of two Caribbean groupers. Mar Ecol Prog Ser 518:239-254

* Scales KL, Lewis JA, Lewis JP, Castellanos D, Godley BJ, Graham RT (2011) Insights into habitat utilisation of the hawksbill turtle, Eretmochelys imbricata (Linnaeus, 1766), using acoustic telemetry. J Exp Mar Biol Ecol 407 : 122-129

* Schofield G, Katselidis KA, Pantis JD, Dimopoulos P, Hays GC (2007) Female-female aggression: structure of interaction and outcome in loggerhead sea turtles. Mar Ecol Prog Ser 336:267-274

Schofield G, Bishop CM, Katselidis KA, Dimopoulos P, Pantis JD, Hays GC (2009) Microhabitat selection by sea turtles in a dynamic thermal marine environment. J Anim Ecol 78:14-21

Selig ER, Bruno JF (2010) A global analysis of the effectiveness of marine protected areas in preventing coral loss. PLOS ONE 5:e9278 
Shimada T, Aoki S, Kameda K, Hazel J, Reich K, Kamezaki N (2014) Site fidelity, ontogenetic shift and diet composition of green turtles Chelonia mydas in Japan inferred from stable isotope analysis. Endang Species Res 25:151-164

Soldevilla MS, Rice AN, Clark CW, Garrison LP (2014) Passive acoustic monitoring on the North Atlantic right whale calving grounds. Endang Species Res 25:115-140

Taquet C, Taquet M, Dempster T, Soria M, Ciccione S, Roos D, Dagorn L (2006) Foraging of the green sea turtle Chelonia mydas on seagrass beds at Mayotte Island (Indian Ocean), determined by acoustic transmitters. Mar Ecol Prog Ser 306:295-302

van Dam RP, Diez CE (1997) Diving behavior of immature hawksbill turtles (Eretmochelys imbricata) in a Caribbean reef habitat. Coral Reefs 16:133-138

van Dam RP, Diez CE (1998) Home range of immature hawksbill turtles (Eretmochelys imbricata (Linnaeus)) at two Caribbean islands. J Exp Mar Biol Ecol 220:15-24

Walcott J, Eckert S, Oxenford HA, Horrocks JA (2014) Use of a towed camera system to investigate benthic habitat use by inter-nesting female hawksbill sea turtles. Endang Species Res 24:159-170

Welsh JQ, Fox RJ, Webber DM, Bellwood DR (2012) Performance of remote acoustic receivers within a coral reef habitat: implications for array design. Coral Reefs 31: 693-702

Weng KC, Pedersen MW, Del Raye GA, Caselle JE, Gray AE (2015) Umbrella species in marine systems: using the endangered humphead wrasse to conserve coral reefs. Endang Species Res 27:251-263

Editorial responsibility: Matthew Godfrey, Beaufort, North Carolina, USA
Wickham H (2009) ggplot2: elegant graphics for data analysis. Springer-Verlag, New York, NY

* Williams JL, Pierce SJ, Fuentes MMPB, Hamann M (2015) Effectiveness of recreational divers for monitoring sea turtle populations. Endang Species Res 26:209-219

Wilson ADM, Krause J (2012) Personality and metamorphosis: Is behavioral variation consistent across ontogenetic niche shifts? Behav Ecol 23:1316-1323

Witt MJ, McGowan A, Blumenthal JM, Broderick A and others (2010) Inferring vertical and horizontal movements of juvenile marine turtles from time-depth recorders. Aquat Biol 8:169-177

Witzell WN (1983) Synopsis of biological data on the hawksbill turtle Eretmochelys imbricata (Linnaeus, 1766). FAO Fisheries Synopsis 137. FAO, Rome

Wood LD, Hardy R, Meylan PA, Meylan AB (2013) Characterization of a hawksbill turtle (Eretmochelys imbricata) foraging aggregation in a high-latitude reef community in southeastern Florida, USA. Herpetol Conserv Biol 8: 258-275

Wood LD, Brunnick B, Milton SL (2017) Home range and movement patterns of subadult hawksbill sea turtles in Southeast Florida. J Herpetol 51:58-67

Wulff JL (2006) Rapid diversity and abundance decline in a Caribbean coral reef sponge community. Biol Conserv 127:167-176

K Zeh DR, Heupel MR, Limpus CJ, Hamann M and others (2015) Is acoustic tracking appropriate for air-breathing marine animals? Dugongs as a case study. J Exp Mar Biol Ecol 464:1-10

Submitted: July 28, 2016; Accepted: January 16, 2017 Proofs received from author(s): March 14, 2017 